\title{
Data Validation Certification Document
}

National Cancer Institute

\section{Source}

National Cancer Institute. Data Validation Certification Document. NCI Thesaurus. Code C115685.

Records pertaining to the certification by an authorized accrediting body confirming the successful implantation, and accurate functionality of a data validation program. 